\title{
Democratization
}

\section{Semi-presidentialism, moderating power and inclusive governance. The experience of Timor- Leste in consolidating democracy}

\section{Rui Graça Feijó}

To cite this article: Rui Graça Feijó (2014) Semi-presidentialism, moderating power and inclusive governance. The experience of Timor-Leste in consolidating democracy, Democratization, 21:2, 268-288, DOI: 10.1080/13510347.2012.732068

To link to this article: http://dx.doi.org/10.1080/13510347.2012.732068

曲 Published online: 27 Nov 2012.

Submit your article to this journal $\widetilde{ }$

Џلll Article views: 294

Q View related articles ¿

View Crossmark data $\nearrow$ 


\title{
Semi-presidentialism, moderating power and inclusive governance. The experience of Timor-Leste in consolidating democracy
}

\author{
Rui Graça Feijó* \\ CES - Centro de Estudos Sociais da Universidade de Coimbra - Portugal, Coimbra, \\ Portugal
}

(Received 16 July 2012; final version received 17 September 2012)

\begin{abstract}
The relationship between the choice of a government system, namely semipresidentialism, and the performance of democracy is the subject of current debate. This article considers Elgie's proposal for a positive correlation between premier-presidential forms of semi-presidentialism and the success of democratic transitions, and discusses the way in which Timor-Leste fits the model as well as the need for a clear view of the incentive mechanisms at play. It further analyses the importance of "independent" presidents with "moderating powers" as a way of achieving inclusive governance and to facilitate democratic consolidation. Contrary to suppositions that attribute a tendency for president-parliamentary regimes to succumb to conflict between the main political actors, the case of Timor-Leste suggests that the definition of the president's role as a "moderator", and the exercise of the function by "independent", non-party personalities counteracts such inclinations with positive effects on democratic consolidation.
\end{abstract}

Keywords: semi-presidentialism; democratic consolidation; independent presidents; inclusive governance; moderating power; incentive mechanisms

\section{Semi-presidentialism and democracy}

The "third wave of democratization" that has marked the last quarter of the twentieth century and the first decade of the new millennium has consecrated semipresidentialism not only as an autonomous tercium genus of democratic systems of government, but also as a popular constitutional solution for emerging, young democratic polities. The strong empirical link that has emerged between semipresidentialism and democratic experiences in various parts of the world, however, has raised at least as many questions about its modalities and the reasons behind its success (and sometimes, failure) as it has provided data to sustain responses and control debates.

Sophia Moestrup, in the first large- $n$ study of semi-presidentialist polities and their performance, concluded that this government system "has performed neither

*Email: ruifeijo@gmail.com 
better nor worse than presidentialism" as far as the propensity to face a breakdown of democracy is concerned. ${ }^{1}$ As Elgie put it, "semi-presidential countries as a whole should not be expected to be systematically associated with any particular outcomes, including the performance of democracy". ${ }^{2}$ However, if semi-presidentialism is regarded as a broad umbrella covering differentiated subtypes, another conclusion may arise. Robert Elgie has used Shugart and Carey's distinction between "premier-presidential" and "president-parliamentary" forms and was then able to suggest that both the prospects for democratic survival and the quality of democratic polities under those subtypes of semi-presidentialism were clearly distinct. Whereas "no premier-presidential democracy has ever been replaced by an authoritarian regime", and countries that opted for this variety seem to have better quality democracies, "president-parliamentary" regimes have often led to the collapse of democracy, and where they have survived they have also shown signs of being of inferior quality. ${ }^{3}$

Besides establishing statistical correlations between the adoption of a particular subtype of semi-presidentialism and vulnerability to a breakdown of democracy and the quality of its performance, Elgie contributes towards an explanation in the form of the differentiated incentive mechanisms at work under one of those systems. By allowing the president to dismiss the government, "presidentialparliamentary" types contribute to creating competition between the president of the Republic (PR) and the prime minister (PM), eventually leading to open confrontation; conversely, the fact that "premier-presidential" types are based on PMs being solely responsible before their parliaments generates an incentive for PRs to cooperate with PMs in order to advance their own positions and defuses temptations to intervene more directly, given the inherent risks of using the power to dissolve the legislature. These differentiated incentive mechanisms would therefore explain why one of these subtypes is expected to generate a more stable democratic performance than the other. ${ }^{4}$

In this article, based on the author's experience as United Nations advisor to the president of the Republic of Timor-Leste and various visits to that country over the years, in the framework of academic projects during which structured interviews with key actors were conducted, I shall address the issue of incentives mechanisms as applied to the case of Timor-Leste. First, a justification of the relevance of the case will be provided, followed by a discussion of the difficulties encountered in applying Shugart and Carey's scheme to Timor-Leste. Then I will identify what seems to be the critical element in the complex system of incentives using a comparative framework to understand Timor-Leste, and will show how it performed in practice. I will argue that in the specific conditions of this country the crucial importance of having "independent" presidents derived from the need to deploy actual mechanisms of checks and balances in a situation characterized by uneven development of those constitutional institutions designed for the effect, and to counterbalance majority rule (with a consequential "losers-lose-all" feature associated with parliamentary games) with a firm commitment to inclusive governance. Finally, I will argue that the success of historical experiences bears 
relation to the adequacy of the institutional response to socio-political characteristics of the polity under consideration.

\section{Scrutinizing Timorese semi-presidentialism}

The two basic assumptions of this section are these: Timor-Leste is (a) a democratic polity that (b) chose a form of semi-presidentialism as its government system, and can thus be used as an illustration of some problems of the relation between this specific government system and democratic consolidation.

The first assumption does not require much elaboration. ${ }^{5}$ Timorese democracy is today established and fits international criteria. In 2010, Polity IV rated the Timorese regime as 7 on a scale from -10 to +10 , in which only grades between +5 and +10 are democracies. ${ }^{6}$ Freedom House, for its part, has consistently rated Timor-Leste as an "electoral democracy" and as a "partly free" country since independence in 2002. Timor-Leste is thus solidly in the camp of democracies.

If we take a view that posits a dichotomy of "democracy" versus "nondemocracy", Timor-Leste must be considered under the first of those terms. If, however, one were to adopt a view in which "democracy" itself is subject to gradation, then these markings signify that there is still a way to go to a consolidated democracy that fulfils at one time all the international criteria and the Timorese's own constitutional provisions: to strengthen the judiciary system and guarantee its independent status, to control violence and discipline the police forces, to safeguard the freedom of the press, to implement legislation allowing the staging of referendums, and much more. Increasing the quality of democracy, a process that is intertwined with the very consolidation of democracy, is an open-ended road. The distance travelled so far is best revealed in the expression that considers Timorese democracy as "relatively stable but unconsolidated". 7 The 2012 round of national elections has shown that Timor-Leste not only adheres formally to democratic principles by holding free and fair elections at regular intervals but has done so in a peaceful way signalled by the fact that a third different president has been elected in as many elections, and the transition of power was achieved in a graceful way. In the regional contexts of Southeast Asia or Melanesia, this is no minor achievement.

The second assumption requires some explanation. Most readings of the Constitution of the Democratic Republic of Timor-Leste (CDRTL) recognize in its articles the basic tenets of a "semi-presidential" form of government. In TimorLeste, the president of the Republic is elected by universal, direct popular suffrage for a mandate of five years. Parliament is equally elected by popular vote for a maximum term of five years and members of parliament (MPs) play a fundamental role in the choice of PM and the support of his government. These two fundamental principles institute a dual structure of authority as a central element in the system of government which allow for its classification as semi-presidential without considering the question of the extent of presidential powers, that is, in line with 
the operational definition provided by Elgie. ${ }^{8}$ If however one considers as a fundamental requirement the existence of "substantial presidential powers" in line with the original Duverger definition, Timor-Leste would still conform given that the constitution empowers the PR to dissolve parliament - the individual power that Jorge Novais singles out as the most significant of all in semi-presidential regimes. ${ }^{9}$

This government system can now be analysed in order to ascertain to what subtype of semi-presidentialism it belongs and to discuss its underlying incentives mechanism. The exercise of ascertaining the precise variety of semi-presidentialism adopted in Timor-Leste is required if any inference is to be made as to the consequences of such a decision. Should we conclude that Timor-Leste has a "premierpresidential" system, a confirmation of Elgie's thesis would ensue and satisfy our quest for an explanation for the success of democratic consolidation; should the case be that the regime requires the classification of "presidentparliamentary" then a more thorough search for the facilitating mechanism is needed. Should we find it difficult to make a final call on a blurred situation, the pursuit and identification of the inherent incentive mechanism becomes more pressing.

Most of the relevant literature refers to Timor-Leste after independence as a "premier-presidential" form of semi-presidentialism. ${ }^{10}$ The overarching influence of the Portuguese constitution is acknowledged by several authors. ${ }^{11}$ Most of them also consider Portugal to be an example of "premier-presidentialism". ${ }^{2}$ However, there is no unanimity. Vasconcelos and Cunha claimed that such classification represented a "dubious option" and more recently the first of these authors squarely classified Timor-Leste as "president-parliamentary". ${ }^{13}$ At this stage, it becomes necessary to operationalize the difference between the two subtypes of semipresidentialism in order to frame a survey of the arguments presented in the case of Timor-Leste. In turn, this will allow a discussion of the pertinence of those classification proposals.

\section{Different subtypes of semi-presidentialism}

The recognition of semi-presidentialism as an independent political category runs parallel with the acknowledgement that it encompasses a wide variation of forms which can be categorized as subtypes. Among various classification proposals one of the most popular distinctions between two subtypes of semi-presidentialism dates back to 1992 when Shugart and Carey first formulated it. ${ }^{14}$ In the course of the last two decades their formulation has been subject to improvements, and Elgie has recently proposed a set of criteria in a vein akin to the one he used in the proposal for the definitional criteria for semi-presidentialism. These aim to avoid problems of unreliability and endogeneity and respond to the need to have parameters as devoid as possible from subjective elements in order to ground comparative studies: references should be limited to the wording of constitutions and 
the number of definitional elements should involve as few constitutive elements as possible. ${ }^{15}$ In this vein, "president-parliamentarism is a form of semi-presidentialism where the prime minister and cabinet are collectively responsible to both the legislature and the president", whereas "premier-presidentialism is a form of semi-presidentialism where the prime minister and cabinet are collectively responsible solely to the legislature". ${ }^{16}$

A direct consequence of this distinction that is easier to perceive is the competence attributed to presidents to dismiss governments. Lobo and Neto defend that "the [critical] criterion is the pattern of relations of political authority established between the president and the government", leading to the following definition:

\begin{abstract}
President-parliamentary regimes are those where the government depends upon the political confidence of the president and the latter appoints the executive without any restrictions. On the other hand, in premier-presidential regimes, governments do not depend on the political confidence of the president, who does not freely appoint the government. ${ }^{17}$
\end{abstract}

However, both these proposals seem to keep elements of subjective qualification of otherwise objective sets of definitional elements: the first one regards the "collective" (as opposed to individual) nature of political responsibility, the second refers to the "political liberty" of presidents rather than to their institutional role.

Both Timor-Leste and Portugal offer their presidents the prerogative to use their political discretion when "the regular functioning of institutions" is at stake. This is a clear situation that transcends mere institutional prerogatives even if it does not configure unrestricted political competences. In cases of presidential prerogatives being strictly limited by institutional functions, the incentive mechanism favouring cooperation is more important than in the alternative case in which actual political competences exist - competences which need not be unrestricted to be considered to be making a difference. Even restricted political competences are likely to introduce an element of potential antagonism as the president can dispose of a mechanism to interfere with, and therefore make political judgements on the performance of, governments. Hence, the qualification is necessary if one aims at establishing a comparative framework.

Objective sets of criteria, even if limited to the wording of constitutions, hardly dispense some form of qualification, and therefore of subjective interpretation. In an effort to stick as much as possible to the goal of objectivity, and incorporating as little qualification as strictly necessary, the definition used henceforth is:

President-parliamentarism is a form of semi-presidentialism where the prime minister and his cabinet are responsible to both the legislature and the president, who retains the power to dismiss the government on political grounds.

Premier-presidentialism is a form of semi-presidentialism where the prime minister and his cabinet are politically responsible solely before the parliament and where the president can only dismiss the government on strictly institutional grounds. 


\section{Classifying Timor-Leste}

The determination of the government system prevailing in any one country is first and foremost a question of constitutional hermeneutics. Hence, the analysis produced by constitutionalist Pedro Bacelar de Vasconcelos requires detailed consideration. Contrary to most of the literature on this issue referred to above, in the view of this scholar Timor-Leste has adopted a president-parliamentary form of semi-presidentialism because of the combination of two constitutional provisions.

On the one hand, section 107 of CDRTL stipulates that " $[t]$ he Government shall be accountable to the President of the Republic and to the National Parliament for conducting and executing the domestic and foreign policy in accordance with the Constitution and the law", thus allowing for presidential competences to oversee and control the legislative action of the government through various means. Those means include the promulgation or veto of legislative bills, the submission of diplomas to the constitutional court for appreciation, the capacity to call a referendum, the control of foreign relation initiatives, or the capacity to address messages both to the people and to the national parliament, thus rendering positive a power of "agenda setting". To this he adds "other means not reducible to a constitutional typified predicament". ${ }^{18}$ In a way, this statement reintroduces the problem discussed by other constitutionalists of the distinction between "explicit" and "implicit" presidential prerogatives, which is a point to bear in mind when the "wording" of a constitution is to be analysed.

This consideration per se does seem to respond in a full and positive manner to the criterion of double responsibility of governments to both the legislature and the president, given the obvious political nature of the president's intervention competences. Vasconcelos, however, dismisses the strength of the argument when he argues that the double responsibility of the government works under precise and uneven terms: the government is institutionally responsible before the president and politically before the parliament. This conclusion seems at odds with the ample scope of political competences entrusted to the president in the view of this very same author.

However, this is not the sole argument sustaining his proposed classification, as section 112-2 of CRDTL reads: "[t]he President of the Republic shall only dismiss the Prime Minister in accordance with the cases provided for in the previous item and when it is deemed necessary to ensure the regular functioning of the democratic institutions, after consultation with the Council of State". The right to dismiss the prime minister derives directly from the double nature of the confidence the government must enjoy, and can be regarded as a positive manifestation of such arrangement. According to Vasconcelos, the judgement as to the need to intervene and insure the regular functioning of the democratic institutions "is autonomous and belongs to the free appreciation of the President of the Republic" who is only limited by the duty to consult with the Council of State at Conselho de Estado. ${ }^{19}$ It is thus a political and not merely institutional decision. That is to say: this interpretation overrides the limitations imposed on the president's 
competences under "normal" circumstances and considers that in cases that are exceptional but nevertheless exist, the president has the political power to dismiss the prime minister. If the political power of dismissal of the PM is not contemplated in the sections that deal specifically with "normal" presidential powers, it is nevertheless explicitly present in the letter of the constitution as a political initiative that presidents can take.

Dennis Shoesmith has argued that the conditions set in section 112-1 of CRDTL do not contemplate "the power to dismiss a prime minister who retains the support of parliament", although he admitted that its wording is actually "a cryptic statement" which allows different interpretations. That is precisely what opens up the door for an enlarged reading of Timorese presidential powers by constitutionalists such as Bacelar de Vasconcelos and local politicians alike. ${ }^{20}$

The case for classifying Timor-Leste as "presidential-parliamentary" rests thus on sound constitutional hermeneutics, as the political power of the president to dismiss the prime minister and his government is part of his constitutional toolbox.

\section{Beyond the wording of the constitution}

Maurice Duverger has suggested that one "cannot limit one's analysis to juridical texts and their customary complements" but should endeavour to devise "the mechanisms through which those rules are applied, and the diversity of strategies they allow". ${ }^{21}$ Hence, some points beyond constitutional hermeneutics need to be addressed to comply with this prescription and bring the analysis back from the realm of constitutionalism into political analysis.

Constitutional provisions define a realm of possibilities that need not be actually exercised but merely remain in the world of eventual legal alternatives. This is one of the reasons why countries like Ireland and Austria where presidents tend to play no more than ceremonial roles are still considered as semi-presidential given the constitutional powers that remain at their disposal. In practical terms, those countries do resemble parliamentary regimes more than their technical classification as semi-presidential. When the Austrian president, Klestil, threatened to take a more active stance at a time when a coalition was being formed with a far-right party without any previous experience in central government, his move was received with surprise but not challenged, and it did in fact contribute to imposing a limit on the scope of political change that was admissible, revealing the true semi-presidential, if dormant, nature of the regime. This suggests that beyond an exegesis of the constitutional provisions, a political analysis should be made of the actual readings of such provisions by the local actors. Curiously, in the case of Timor-Leste, and in spite of what has already been presented, this points paradoxically to an active role in the selection of government (mainly in situations of no parliamentary absolute majority) and to a restrained view of the power to dismiss the prime minister.

The absence of a clear single-party majority in the National Parliament in 2007 gave the president extended powers in the selection of the prime minister. ${ }^{22}$ After 
having considered the suggestion for a government of "national unity" that failed to get enough support, President Ramos-Horta chose to invite the leader of a postelectoral coalition instead of the party with the plurality of the vote. Arguably, he waited some time in order to ascertain whether the coalition was sound and capable of enduring, and only appointed the prime minister after the coalition showed its consistency by electing the president of the National Parliament in open confrontation with a candidate presented by the largest party, thus merging an institutional approach with a clear political choice. By insisting he had room for a choice and not to limit his action to observe the fulfilment of a set of rules outside his reach, Ramos-Horta contributed to the idea of the double dependence of government.

There was at least one instance in which conditions existed for a PR to invoke the breakdown in the regular functioning of democratic institutions to force the dismissal of the PM on his own political initiative - an extreme measure to face an extraordinary occasion. That occasion arose in May 2006 at the height of the political crisis initiated by the military "petitionaries". At one point, members of the police and the army met head-on in the streets of Dili, and the whole security apparatus collapsed. Two ministers were then evicted (officially they resigned). But the PR failed to dismiss the PM. A few days later, tensions between the two had grown to the point that the PR threatened to resign unless the PM would tender his own resignation. The PM then resigned but kept his own majority in parliament which was not dissolved. The situation was dealt with as if the PR had no power to take the political initiative to dismiss the PM.

Arguably, if the competence to dismiss the PM had been viewed by all political agents as an effective tool at the beginning of the political crisis, the level of confrontation might have been less acute, because either the PM would have refrained from the political move that raised the president's opposition, or the president would have acted swiftly upon the incident that triggered the crisis and replaced the government before tensions could grow stronger.

In an interview with the present author, President Ramos-Horta was asked to grade the whole panoply of his powers from 0 to 10 . Regarding the power to dismiss the prime minister his answer was " 20 " - the only time he felt rhetorically compelled to go beyond the grading scale. He added: "I have not exercised this power and I hope I shall not need to in the future". The implication is clear that he regards this to be a component of the president's political toolbox.

In brief, in spite of constitutional provisions granting the PR the power, under extreme conditions, to dismiss the PM, the fact remains that this particular power assumes an ambiguous position in the president's arsenal of political competences. It has never actually been used - maybe never actually contemplated as a possible course of action - even if the opportunity has arisen at least once.

The considerations discussed above - both the president's historical capacity to intervene in the formation of governments and the actual restrictions on the use of the presidential power to dismiss the PM - add contradictory signs to the scrutiny of the Timor-Leste's specific form of semi-presidentialism. The conclusion 
that it is possible to draw is that in those constitutional terms that Elgie proposes which should constitute the backbone of any classification of government regimes, Timor-Leste possesses a presidential-parliamentary form of semi-presidentialism, although all actors have so far behaved as if the critical competence to dismiss the prime minister was not actually inscribed in the constitution, and thus was a premier-presidential type of government system.

The classification of Timor-Leste as a "president-parliamentary" subtype which nevertheless behaves as "premier-presidential" implies that the reasons for the success of its democratic consolidation must be sought in specific mechanisms put in place under semi-presidentialism, but which do not conform easily with the schematic assumptions proposed by Elgie. We need to know more than the model implies. My suggestion is that the status of PRs as "independent" figures may create incentive mechanisms to cooperation that facilitate democratic consolidation.

\section{"Independent" presidents and political parties}

In his most recent book, Elgie states that one topic deserving further attention in studies of semi-presidentialism is the figure of "independent" presidents. ${ }^{23}$ The literature on Timor-Leste suffers from cursory analyses of this issue, as some authors overlook the specificity of this instance. Ben Reilly considers the period $2002-$ 2006 when Xanana was president and Alkaitiri prime minister as an instance of "divided executive", and Dennis Shoesmith uses the expression "conflictual cohabitation" to describe the same situation. "Cohabitation" as a precise concept in the frame of semi-presidential regimes refers to instances when the president and the government are supported by rival political factions. In the succinct wording advanced by Elgie, "cohabitation" is "the situation where the president and the prime minister are from opposing parties and where the president's party is not represented in the cabinet". 25

In fact, not all polities follow a model in which political parties constitute the sole expression of political activity, and where the "natural" aspiration of party leaders is to become president of the Republic. Duverger claimed that "in France [...] the whole party system and the majoritarian system have been organized around the election of a President by universal suffrage", and thus the coincidence of party leadership with the presidency is the rule. ${ }^{26}$ But there are different cases, of which Portugal can be regarded as an example. Carlos Jalali states that in this country the government, and therefore the position of prime minister, "has been the central locus of political leadership throughout the democratic period and remains the key political prize for parties". 27

It is therefore necessary to admit that political parties have no claim to the monopoly of political representation, and that democratic regimes accommodate other forms of expression of their citizens' preferences. "Independent presidents" may be one such formula. But what are we talking about when we mention the existence of an "independent president"? 
Two different dimensions converge on the notion of "independent president": one relates to the circumstances of the person who is elected to the post, the other refers to the constitutional provisions for his function. Both need to be scrutinized in order to clarify the actual meaning of the expression, and to reduce the level of fluctuation in the use of the term.

On the first sense of the term, a strict reading of the expression would require that an "independent" president be defined by not being a member of any political party. This would apply, among others, in the case of presidents issued from the military forces (General Eanes in Portugal, 1976-1986), or who are prominent intellectuals (Vaclav Havel in Prague after the Velvet Revolution), academics like Mary Robinson from Ireland (1990-1997) or indeed figures issued from the diplomatic or judicial worlds such as Rudolf Kirchschlager of Austria (19741986) or Christos Sartzetakis of Greece (1985-1990).

However, a more generous reading can encompass in this notion politicians who do not hold the leadership of the parties to which they are formally affiliated. It is the case of senior figures, sometimes former prime ministers or party leaders, who are widely regarded as having reached a "senatorial" status that elevates them above strict party competition and favour their aspiration to hold a post in line with such requirements. Portuguese politicians like Mario Soares and Jorge Sampaio could claim that status after having served as party leaders. Both insisted their party allegiance - often accompanied by less-than-perfect relations with current party leaderships - was a minor consideration in their broad appeal to electors beyond the reaches of the party and their promise not to follow strict partisan policies.

The personal circumstances of the individuals concerned is but one aspect of our problem, the other being the actual definition of the presidential function and the relationship it entertains with the former aspect. Again we turn to Maurice Duverger, who distinguishes three scenarios: the president as leader of the majority, as leader of the opposition to the parliamentary majority, and a "president without majority". ${ }^{28}$ The first two scenarios both fit with a situation in which the role of the president is active in governmental matters; the last one calls for an understanding of the presidential role in line with the possibility of an "independent" president not in the sense of individual features but as an institutional model. It is precisely this idea that the president has no majority of his own, be it in favour or opposed to that of the prime minister - which has been symbolically proclaimed by the Portuguese President Mario Soares on the night of his first election (1986) when he said the "presidential majority is over" and returned his party card - and retains his independence in relation to the prime minister and his government, that can provide us with grounds to identify "independent presidents". Several metaphors have been suggested to render the type of function expected from this sort of president; amongst those, the images of the "tip of the scale" and the "lubricating oil" capture the holistic nature of the functions ascribed to presidents who have to look not only after matters of the government strictu sensu but of the whole institutional architecture. They are called to perform a critical role in 
the system of checks and balances, and the notion of a "moderating power" is often advanced as a way of categorizing this model.

No doubt exists that one "independent" president (in the narrow, individual sense) may be elected and perform his duties in close articulation with a given faction of parliament; and that a member of a political party can posit his candidature even when the institutional "independence" of presidents is a constitutional provision. The most frequent cases, including the case we are discussing, are those of a convergence of both notions in one historical instance. For the sake of the argument developed in this article, an "independent" president is a political figure who does not hold the current leadership of any political party (even if he is identified with a given political party of which he may retain formal membership, or with a "political family" in broad terms) and whose role is defined in such a way as to make clear that his position is not of either rivalry or active support to any prime minister.

This approach, combining the personal features of presidents with the institutional definition of their mandate, and placing greater emphasis on the latter rather than on the former, aims to avoid the pitfalls of situations in which a president may be individually "independent" but have followers in parliament who behave in a coordinated manner with him either in support or in opposition to the current government. ${ }^{29}$

Constitutional provisions for the first term of this understanding are given by the requirement that all candidates submit their bid with the support of a number of registered electors. In Timor-Leste, this is further supplemented by the need to present a minimum number of proponents from all districts of the country to demonstrate his or her broad appeal. The official backing of a registered political party does often occur but does not replace the need to submit the candidacy with evidence of personal, individual support which in turn reduces the perceived dependence of candidates on political parties.

As for the second part of the problem, it could be argued that the ascribed model functions of "independent" presidents match better the "premier-presidential" type of semi-presidentialism than the "president-parliamentary" precisely because the first one is the formula under which a political competition between the two holders is avoided. "President-parliamentary" subtypes, with the consequent possibility of "cohabitation", seem to go better with partisan presidents rather than independent ones, given that presidents are then caught in the dichotomy of being either in favour of or against the prime minister. However, if one retains a strict definition such as the one proposed by Elgie, then one will find instances of "presidentparliamentary" types with "independent" presidents. Timor-Leste is one case.

All three presidents (Xanana Gusmão, 2002-2007; José Ramos-Horta, 20072012; and Taur Matan Ruak, elected 2012) presented themselves to the electors as "independent". Xanana faced a candidate fielded by a political party (Xavier do Amaral from Associação Social-Democrata Timorense), obtained the support of most other parties (but not of the ruling party, Fretilin) and scored a landslide victory with $83 \%$ of the vote. In 2007 , José Ramos-Horta, who was not affiliated 
to any party, secured among others the support of Xanana's CNRT since the first ballot, and defeated in the run-off a party candidate (Lu Olo from Fretilin) by a comfortable margin (69\%). In the last elections, Taur Matan Ruak, former guerrilla commander turned the first chief of staff of the new country's armed forces, presented his bid without party backing, then secured CNRT's support before the first round, and soundly defeated in the run-off Lu Olo, again supported by Fretilin (61\% to $39 \%)$. Clearly, the Timorese have always chosen a candidate who presented his credentials as "independent" and defeated those who made their candidacy depend on political parties. ${ }^{30}$

Having established an objective basis for the consideration of what an "independent president" is, and observed the broad terms that allow Timor-Leste to be used as an illustration, we can now proceed to a discussion of the implications of this case.

\section{The case for "independent" presidents}

The existence of "independent presidents" is perhaps more important in cases of young democracies and in processes of transition, on two counts: the inclusiveness it may offer, and the establishment of actual mechanisms of checks and balances at a time when constitutional institutions are making their first steps.

It is known that transition and consolidation periods call for inclusive forms of governance. For instance, the adoption of proportional representation in electoral legislation has been positively associated with the success of transitions precisely because of its inclusive nature. ${ }^{31}$ The parliamentary game, by virtue of the majority versus minority mode of decision-making (which is certainly not the only mechanism at play in transition periods when the commonality of the political architecture is under construction), often results in temporary exclusion for periods of time that may seem too long to the parties concerned, and induces extremist forms of political behaviour. ${ }^{32}$ Some assumptions regarding the supposedly widespread adoption of best practices in parliament, such as ascribing a prominent role to opposition leaders, which sustain the arguments of Juan Linz, are not always observed. ${ }^{33}$ In Timor-Leste, for instance, PM Alkatiri (2002-2006) did not come even once for question time in parliament - an example that provides evidence for the fact that parliament rules, before being a juridical matter, are, in the words of Michel Lesage, "a cultural model of political tolerance" that takes its own time to grow. They have been compared to a lush English lawn which is so pristinely green because it was sown before it rained over it for four hundred years. In the meantime, as the same author expressed, "[a]ll the actors in the transition process [...] wish to promote democracy and desire to offer themselves the juridical means to avoid being excluded from the ensuing political game". 34

A figure that is not compromised with one single actor in the process - both in his personal capacity as a citizen and in his function as president - but appeals to a wide, diversified constituency as "independent presidents" notionally do, may be said to represent to all stakeholders a form of guarantee against exclusion from 
the central political arena. The critical question is thus: what are the mechanisms that provide political incentives towards cooperation and foster consensus?

The existence of "independent" presidents weighs on the issue of incentive mechanisms. It can be argued that where executive power is reserved for political competition between parties, the realm of activity of a president does not overlap with that of the prime minister, and therefore reduces the scope for attrition. An "independent" president may wish to influence the overall policy of a government, and can certainly determine some limits to government action (for instance, through the exercise of veto powers, by calling a referendum or directing a message to parliament); but he may seldom, if at all, actively propose a course of action, as his initiative powers are limited. He may however retain powers of intervention in extreme situations, like the capacity to dissolve the assembly, or even to dismiss the prime minister. Therefore, both the prime minister and the president are induced to negotiate.

Timor-Leste offers an example of a constitution that defines the role of the president as a political moderator, coupled with the successive election of "independent" candidates for the post. It is particularly well suited to illuminate the question at stake. The following section describes the way this particular form of governance has operated in the country, and discusses its implications for the wider debate.

\section{Timor-Leste's "independent" presidents}

The three presidents Timor-Leste has elected since 2002 have all been "independent" candidates who defeated adversaries coming directly from political parties. They all won their victory by substantial margins of votes which gave them a direct and strong popular mandate. This fact is certainly made easier by virtue of the choice of a two-round type of presidential elections, which ensures that the elected candidate must have polled more than half the votes cast, and thus contributes to the existence of a personal element in the final victory that differentiates it from strict party support. ${ }^{35}$

All three winners presented themselves as distanced from the realm of party political competition in an attempt to define a role for the president of the Republic as distinct from the one ascribed to a prime minister. In 2007 Ramos-Horta moved from the first ballot in which parties fought for their own electorate, into a second ballot where distance from parties seems to have been a condition of success as it inspired in the parties' electorate enough confidence they were being protected by not electing a member of a rival organization. The second round of the 2007 election permitted that Ramos-Horta be regarded as a figure capable of creating some form of unity above party lines. Both in the case of Xanana and Ramos-Horta it is fair to say that the elected presidents did not have an inclination to form a government that replicated their own views. Neither was a party leader.

On the other hand, parties that filed candidates did not always choose their own leader to stand at the election (for example, this was the case with Lucia Lobato 
from PSD in 2007, and most notably with Lu Olo who is Fretilin's chairperson but not executive leader).

As a matter of fact, unlike some countries with other varieties of semi-presidentialism - of which France may be an example - political parties did not form mostly around presidential candidates but rather around candidates to the post of prime minister, presidents being regarded as somehow above party political competition. ${ }^{36}$ The combination of these remarks points to one conclusion: the role of the president is not regarded as the top job in the executive branch, and the supreme ambition of a party leader is rather to fight for the head of government than to clinch the presidency. This explains the reason that motivated Xanana not to seek re-election but rather to fight for the post of prime minister in 2007. The Portuguese example, rather than the French, is perhaps the best parallel.

Timorese presidents have thus shaped their role mostly outside the competitive game for executive power and concentrated on creating conditions in a young and relatively under-developed democracy to complement the confrontational character of parliamentary politics, in which the logic of majority versus minority is determinant, with measures destined to increase the scope of inclusiveness of different streams of opinion. Those who were engaged in promoting democracy in the country feared above all that the combination of majority rule and alternate law would mean many would be excluded from the actual political game in the critical phase of democratic consolidation.

Xanana's branching out over wide sectors of the political spectrum has been acknowledged, while Ramos-Horta's term of office has received scant attention so far, but can be regarded in the same light. ${ }^{37} \mathrm{~A}$ few examples will illustrate this point.

One case that can be equally attributed to both PRs is the criteria used in the appointments that fell under their jurisdiction. The Council of State is one possible example, given that presidents are required to appoint five members to that consultative body. Ramos-Horta appointed one woman from Oecussi (to be sensitive to gender and regional criteria); a former leader of the Youth National Council, himself regarded as a balanced and independent personality; the chancellor of the public university, who was also a member of that council under Xanana; a former colleague in the two governments in which he had served, unaffiliated to any party; and a politician from one of the parties that had not reached the threshold for parliamentary representation but nonetheless, considered as a whole, had polled more than $10 \%$ of the popular vote. This reveals openness from the president who did not seek to be surrounded by loyalists, but rather to include differentiated strata of Timorese society who had reasons to feel pulled into the arena where politics in the wider sense were being discussed.

In spite of having fought the second ballot against a Fretilin-sponsored candidate, Ramos-Horta made several openings to that party after this party was not included in Xanana's government. He appointed two former ministers, Roque Rodrigues and Alcino Baris, to serve in the Superior Council for Defense and 
Security, the former being also nominated to serve in his office as senior advisor. These attitudes reveal the extent to which a PR can be carried to place his actions outside the realm of majority versus minority positions. As such, the Timorese presidents seem to fit Duverger's third case: presidents without majority. $^{38}$

Of course, there are also examples of some form of rivalry and potential problems arising when presidents sought to take direct action. The veterans issue is a case in point of Xanana's term of office. He felt it was his duty to give consistent form to his constitutional mandate to reinforce the role of the Resistance in the creation of national identity (CRDTL, section 11). Pursuant to that idea, he sponsored - with the support of Alkatiri's government - the creation of the Museum and Archive of the Resistance, which treats with credible historical accuracy the different sectors of the movement. He also set up a team in the presidential office to launch the basis for the reconnaissance of the Resistance networks. Alkatiri responded by creating a junior position in his government to deal with the same issue, and agreement on practical matters could not be reached. The Resistance network was important in Xanana's later moves to establish his own party, and the veterans issue was given ample attention both by the PM and the PR after $2007 .^{39}$

These examples suggest that there is a margin of indeterminacy regarding what exactly a PR is entitled to do on his own initiative, and that more than a question of constitutional exegesis, the politics of the matter, that is, the nature of the relations between the PR and the PM, are the real issue at stake. Hence, it might be considered that "presidential powers are de jure and de facto of a variable geometry nature". 40 This flexibility seems to adapt to a situation in which institutions are not yet consolidated, as well as to a profile of the president removed from executive power - an "independent" president.

Data presented above suggest that actions undertaken by presidents, in a more or less consensual manner, have generally resulted in positively opening up the realm of power beyond the executive to sectors not necessarily identified with the parliamentary majority, and thus enlarged and intensified the inclusive nature of democratic political institutions. The capacity to conduct policies of this nature has been strengthened by the fact that while they were serving their mandates, neither PR was a direct participant in the competitive struggle for executive power staged by political parties which took place mostly in parliament. Shoesmith has shown how weak this critical institution was. ${ }^{41}$ Similar conclusions might be derived from an analysis of the deployment of the judicial sector. Without stepping directly into the shoes of other constitutional bodies that were "under-developed", the first two Timorese presidents paid considerable attention to the need to exert an extended role in the control of government action. In so doing, they revealed the importance of other mechanisms to produce both checks on government and balance majority rule with inclusiveness. For this goal, the fact that both presidents fit into the category of "independent" in the narrow sense is analysed by RamosHorta: ${ }^{42}$ 
In our country, in our situation, the ideal profile for a president, among other characteristics, resides in his not being affiliated to any political party. It is extremely difficult for someone who is a party leader to be elected President of the Republic. But if he were to succeed, the dialogue with other actors would be difficult. It would be very difficult for him to build bridges, and he would waste most of his time trying to prove he really is the president of all Timorese.

And he added:

The vocation of large political parties is to hold the reins of government. Thus, what really matters for such parties are legislative elections, not presidential ones.

The implicit distinction between "governing" and "ruling" (a function reserved for presidents) is thus critical in the perspective of "independent" presidents who can be regarded in parallel to the role that constitutional monarchs exert in our time, albeit with reinforced mandates.

\section{Presidents and the rooting of democracy}

The president of the Republic appears as a figure with a pivotal role in the process of rooting democracy as the common focus of the widest range of civic organizations. This process was characterized by the fact that the different branches of power (executive, legislative, judiciary) were unevenly developed, with a great emphasis placed on the executive - a situation described by Anthony L. Smith as "[s]trong government, weak state". ${ }^{43}$ Trying to avoid falling into the trap of being either friend or foe of the executive, as would be "normal" if they had strong party affiliations, presidents endeavoured to uphold and project their role as moderators of the public debate that ranged beyond the reaches of formal political institutions that were encouraged to express and defend the pluralism of democratic disputes. In a word, presidents facilitated inclusiveness of the new regime and contributed to install a form of power sharing that Arend Lijphart places at the heart of the requirements for a successful institutional design. ${ }^{44}$ This need for inclusive governance has also been noticed by Larry Diamond who stated that:

If any generalization about institutional design is sustainable ... it is that majoritarian systems are ill-advised for countries with deep...emotional and polarizing divisions. $^{45}$

To fulfil this role, the fact that presidents were elected for a non-executive position on a non-partisan platform, and that neither was a party leader at the time, was a major positive factor.

Incentives to foster inclusiveness at a time when this factor was critical in the process of rooting democracy came from the fact that the presidents and the prime ministers defined their respective roles as pertaining to different levels of 
performance, not to competition or superimposition between them. The power of the president to dismiss the prime minister was real, although restricted to very extreme situations; but it was never exercised (and maybe not even perceived to be a practical tool for a good deal of the time under consideration), not even in times of severe confrontation. The fact that presidents did not issue from party machines, either as leaders or prominent party figures, but rather cultivated their status as independent moderators, was a major facilitator of the system that deserves to be underlined for the results it has so far produced, and which seems to be in line with Duverger's view on this system of government as an embodiment of the "moderating power" that Benjamin Constant wished in vain some constitutional monarchies might provide. ${ }^{46}$

Returning to our initial question, the mechanism that was instituted in TimorLeste to foster cooperation and defuse tension between two political figures with their own popular, direct mandates as the president of the Republic and the prime minister, is greatly tributary to the definition of the president as an "independent" figure. This definition of the presidential role as a moderator coupled with the possibility of dismissing the prime minister - the single instance that is identified in the literature as militating against that goal and favouring the emergence of rivalry and competition between the two leading figures of the state - as well as the power to dissolve parliament, has been critical in the establishment of a wide and inclusive political platform to counteract the negative aspects of majority rule and set the table for a banquet in which all stakeholders of the political process could find a place. The role of a president without a supporting party machine who is given an arbitral position in the system seems to require that his powers be not defined by its extension in order to prevent clashes with the prime minister, but comprehend critical weapons to grant him voice in assuring "the regular functioning of political institutions" $" 47$ and participate in the strategic definitions of his polity. It is therefore important to pursue the study of "independent presidents" and the role they can play in rooting young, fragile democracies.

\section{Acknowledgements}

This article has been produced in the context of FCT grant SFRH/BPD/71238/2010, and also of FCT Research Project 'Co-habitations: Dynamics of Power in Lautém (TimorLeste)' PTDC/CS-ANT/118150/2010. Visits to Dili took place over a long period, starting in 2004, and include one year (2005/06) in which I was a UN advisor to the Presidency of the Republic. Later visits have benefited from the generous hospitality of the Fundação Oriente and the sympathy of its former local director Álvaro Antunes. I would like to express my heartfelt gratitude to José Ramos-Horta, Mari Alkatiri and Xanana Gusmão for extensive, strucutured interviews conducted in November 2009, November 2011 and April 2012. Extensive research support was provided in my visits to Dili by Dionisio Babo Soares, João Gonçalves, João Saldanha, José Teixeira, Lurdes Bessa, Roque Rodrigues, Virgilio Smith, and also by Ana Filipa Carvalho, José Carlos Aragão, José H. Meirelles, Maria Amado, Nuno Vasco Oliveira and Paulo Vieira. In Brussels, I was able to benefit from the long experience and companionship of Sonia Neto. Ideas expressed in this article were discussed many times over with David Goldey and Michael Leach, who gave their 
best to bring my arguments out in a form I would not have achieved without their relentless support. Susana Viegas challenged my schematic assumptions from the corner where love sleeps. Of course, all the responsibility for any shortcomings and plain errors that may subsist rests solely on my shoulders.

\section{Notes}

1. Moestrup, "Semi-presidentialism in Young Democracies," 30.

2. Elgie, Semi-presidentialism, 27.

3. Samuels and Shugart, Presidents, Parties, Prime Ministers, 260.

4. Elgie, Semi-presidentialism, 175-7.

5. For further elaboration, see Feijó, "Semipresidentialism."

6. http://www.systemicpeace.org.

7. Elgie and Moestrup, Semi-presidentialism Outside Europe, 239.

8. Sartori, Constitutional Engineering; Elgie, Semi-presidentialism. For a different view see Kingsbury, "Clarity without Convention."

9. Duverger, "New Political System"; Novais, Semipresidencialismo.

10. Elgie and Moestrup, Semi-presidentialism Outside Europe, 243; Elgie, Semi-presidentialism, 29; Shoesmith, "Timor-Leste: Semi-presidentialism," 225-6; Lobo and Neto, Semi-presidencialismo, 271-2; Reilly, "Semi-presidentialism and Democratic Development," 118.

11. Gouveia, Constituições, 24-32; Vasconcelos, "Transição em Timor-Leste," 70-1; Vasconcelos, Constituição Anotada, 3.

12. Elgie, Semi-presidentialism, 29; Lobo and Neto, Semi-presidencialismo, 272. Portugal was considered "president-parliamentary" up to the constitutional revision of 1982. For some, changes introduced in 1982 mean that the country ceased to be semi-presidential altogether. For a comment on these see Jalali, "The President is Not a Passenger."

13. Vasconcelos and Cunha, "Semi-presidencialismo em Timor," 235; Vasconcelos, Constituição Anotada, 343.

14. Shugart and Carey, Presidents and Assemblies, 23-4; Elgie, Semi-presidentialism, $27-8$.

15. Elgie, Semi-presidentialism, 28.

16. Ibid.

17. Lobo and Neto, Semi-presidencialismo, 271.

18. Vasconcelos, Constituição Anotada, 293, 353-4.

19. Ibid., 363.

20. Shoesmith, “Timor-Leste: Semi-presidentialism," 226.

21. Duverger, "Régime Semi-présidentiel," 902.

22. Feijó, "Counting Votes."

23. Elgie, Semi-presidentialism, 185-6.

24. Reilly, "Semi-presidentialism and Democratic Development"; Shoesmith, "TimorLeste: Semi-presidentialism," 227.

25. Elgie, Semi-presidentialism, 12.

26. Duverger, Systéme Politique Français, 510.

27. Jalali, "The President is Not a Passenger," 160.

28. Duverger, Systéme Politique Français, 516-17.

29. Elgie, Semi-presidentialism, 185-6.

30. Feijó, "2012 Elections in Timor-Leste."

31. Tansey, Regime-building, 57-8.

32. Frison-Roche, Modèle Semi-presidentiel.

33. Linz, "Presidential or Parliamentary Democracy," 15. 
34. Lesage, "Preface," ix.

35. However, short margins are known to happen in many countries that have adopted the same system (for example, Portugal or France). The positive effects of the two-round type of election on governability have been discussed by Sabsay ("El Ballotage") and Martinez (Semi-presidencialismo, 28).

36. Duverger, Systéme Politique Français, 510.

37. Simonsen, "Authoritarian Temptation."

38. Duverger, Systéme Politique Français, 516-17.

39. Virgilio Smith, interview; International Crisis Group, “Timor-Leste's Veterans: An Unfinished Struggle?"

40. Conac, "Presidentialisme," 816.

41. Shoesmith, "Remaking the State."

42. Ramos-Horta, interview.

43. Smith, "Strong Government."

44. Lijphart, "Constitutional Design," 96-9.

45. Quoted in ibid., 100.

46. Duverger, "Régime Semi-présidentiel," 903.

47. Democratic Republic of East Timor Government, Constitution of the Democratic Republic of Timor-Leste.

\section{Notes on contributor}

Rui Graça Feijó is Associate Researcher at the Centre for Social Studies (CES), University of Coimbra, and currently Visiting Scholar in Politics, Nuffield College, University of Oxford. He has lived in Timor-Leste, where he was UN advisor to President Xanana Gusmão, and has been an observer to the electoral processes in 2007 and 2012. His interests include the formation of national identity, electoral institutions and their performance, and comparative approaches to the role of semi-presidentialism in processes of democratic consolidation. Apart from articles in academic journals and book chapters, he has published Timor-Leste: Paisagem Tropical com Gente Dentro (Lisbon, 2006).

\section{Bibliography}

Conac, Gérard, "Presidentialisme." In Dictionnaire Constitutionnel, edited by Olivier Duhamel and Yves Mény, 814-817. Paris : Presses Universitaires de France, 1992.

Democratic Republic of East Timor Government. Constituição da Republica Democrática de Timor-Leste [Constitution of the Democratic Republic of Timor-Leste]. Dili: Assembleia Constituinte, 2002.

Duverger, Maurice. “A New Political System Model: Semi-presidential Government.”European Journal of Political Research 8, no. 2 (1980): 165-187.

Duverger, Maurice. "Régime Semi-présidentiel." In Dictionnaire Constitutionnel, edited by Olivier Duhamel and Yves Mény, 901-904. Paris: Presses Universitaires de France, 1992.

Duverger, Maurice. Le Systéme Politique Français. Droit Constitutionel et Science Politique. Paris: PUF, 1996.

Elgie, Robert. Semi-presidentialism: Sub-types and Democratic Performance. Oxford: Oxford University Press, 2011.

Elgie, Robert, and Sophia Moestrup. Semi-presidentialism Outside Europe. London: Routledge, 2007.

Elgie, Robert, Sophia Moestrup, and Yu-Shan Wu. Semipresidentilalism and Democracy. Basingstoke: Palgrave Macmillan, 2011. 
Feijó, Rui Graça. "Counting Votes that Count: A Systemic Analysis of the 2007 Timorese Elections and the Performance of Electoral Institutions." In State, Society and International Relations in Asia, edited by M. Parvizi Amineh, 105-118. Amsterdam: Amsterdam University Press, 2010.

Feijó, Rui Graça. “Semipresidentialism' and the Consolidation of Democracy." In The Politics of Timor-Leste, edited by Michael Leach and Damien Kingsbury. Ithaca, NY: Cornell Southeast Asia Program, forthcoming.

Feijó, Rui Graça. "The 2012 Elections in Timor-Leste," forthcoming.

Frison-Roche, François. Le "Modèle Semi-presidentiel" comme Instrument de la Transition en Europe Post-communiste: Bulgarie, Lituanie, Macédoine, Pologne, Roumanie et Slovénie. Bruxelles: Bruylant, 2005.

Gouveia, Jorge Bacelar. As Constituições dos Estados de Língua Portuguesa, 2nd ed. Coimbra: Almedina, 2005.

International Crisis Group. "Timor-Leste's Veterans: An Unfinished Struggle?" Asia Briefing No. 129, 18 November 2011.

Jalali, Carlos. "The President is Not a Passenger: Portuguese Evolving Semi-presidentialism." In Semi-presidentialism and Democracy, edited by Robert Elgie, Sophia Moestrup, and Yu-Shan Wu, 156-173. 2011. Basingstoke: Palgrave Macmillan.

Kingsbury, Damien. "Timor-Leste's Constitution: Clarity without Convention." In The Politics of Timor-Leste, edited by Michael Leach and Damien Kingsbury. Ithaca, NY: Cornell Southeast Asia Program, forthcoming.

Lesage, Michel. "Preface." In Le "Modèle Semi-presidentiel" comme Instrument de la Transition en Europe Post-communiste: Bulgarie, Lituanie, Macédoine, Pologne, Roumanie et Slovénie, edited by François Frison-Roche, i-xvi. Bruxelles: Bruylant.

Lijphart, Arend. "Constitutional Design for Divided Societies." Journal of Democracy 15, no. 2 (2004): $96-109$.

Linz, Juan J. "Presidential or Parliamentary Democracy: Does it Make a Difference?" In The Failure of Presidential Democracy: Comparative Perspectives, Vol. 1, edited by Juan J. Linz and Arturo Valenzuela, 3-87. Baltimore, MD: The Johns Hopkins University Press, 1994.

Lobo, Marina Costa, and Octavio Amorim Neto. O Semipresidencialismo nos Países de Lingua Portuguesa. Lisboa: Imprensa de Ciências Sociais, 2009.

Martinez Martinez, Rafael. El Semipresidencialismo: Estúdio Comparado. Barcelona: Institut de Ciencies Politiques i Socials, 1998.

Moestrup, Sophia. "Semi-presidentialism in Young Democracies: Help or Hindrance?" In Semipresidentalism Outside Europe, edited by Robert Elgie and Sophia Moestrup, 30-55. London: Routledge, 2007.

Novais, Jorge Reis. Semipresidencialismo, Volume 1. Teoria do Sistema de Governo Semipresidencial. Coimbra: Almedina, 2007.

Ramos-Horta, José. "O Modelo Semipresidencialista que Temos é Adequado à Realidade Timorense." In O Semipresidencialismo Timorense. História, Politica e Desenho Institucional, edited by Rui Graça Feijó. Coimbra: CES/Almedina, forthcoming.

Reilly, Benjamin. "Semi-presidentialism and Democratic Development in East Asia." In Semi-presidentialism and Democracy, edited by Robert Elgie, Sophia Moestrup, and Yu-Shan Wu, 117-133. Basingstoke, NY: Palgrave Macmillan.

Sabsay, Daniel Alberto. "El Ballotage: Su Aplicación en America Latina y la Gobernabilidad." Cuadernos del CAPEL 34 (1992): 15-81.

Samuels, David, and Matthew Shugart. Presidents, Parties, Prime Ministers: A Framework for Analysis. Cambridge: Cambridge University Press, 2010.

Sartori, Giovanni. Comparative Constitutional Engineering. Basingstoke; London: Palgrave Macmillan, 1994. 
Shoesmith, Dennis. "Remaking the State in Timor-Leste: The Case for Constitutional Reform." Paper presented at the 17th Biennial Conference of the Asian Studies Association of Australia, Melbourne, July 1-3, 2008.

Shoesmith, Dennis. "Timor-Leste: Semi-presidentialism and the Democratic Transition in a New, Small State." In Semi-presidentialism Outside Europe, edited by Robert Elgie and Sophia Moestrup, 219-236. London: Routledge, 2007.

Shugart, Matthew Soberg and John M. Carey. Presidents and Assemblies: Constitutional Design and Electoral Dynamics. Cambridge: Cambridge University Press, 1992.

Simonsen. Sven Gunnar. "The Authoritarian Temptation in East Timor - Nation Building and the Need for Inclusive Governance." Asian Survey, 46, no. 4 (2004): 575-596.

Smith, Anthony L., "Timor-Leste: Strong Government, Weak State." Southeast Asian Affairs (2004): 277-294.

Tansey, Oisin. Regime-building: Democratization and International Administration. Oxford: Oxford University Press, 2009.

Vasconcelos, Pedro Bacelar de. Constituição Anotada da República Democrática de TimorLeste. Braga, Direitos Humanos - Centro de Investigação Interdisciplinar, Escola de Direito da Universidade do Minho, 2011.

Vasconcelos, Pedro Bacelar de. "A Transição em Timor-Leste (1999-2002)." In TimorLeste da Nação ao Estado, edited by Rui Centeno and Rui Novais, 57-71. Porto: Afrontamento, 2006.

Vasconcelos, Pedro Bacelar de., and Ricardo Sousa da Cunha. "Semipresidencialismo em Timor: Um Equilíbrio Institucional Dinâmico num Contexto Crítico." In $O$ Semipresidencialismo nos Países de Língua Portuguesa, edited by Marina Costa Lobo and Octavio Amorim Neto, 231-260. Lisboa: Imprensa de Ciências Sociais, 2009 . 